\section{Europe launches new-technology education project by satellite}

Paris

Europe last week joined the world of higher education by satellite television with the launch of the European Programme of Advanced Continuing Education (known as EuroPACE). The aim is to provide industrial Europe with up-to-date educational courses in six new-technology areas. But the project has also raised questions about the future linguistic balance of Europe.

EuroPACE, inspired by the US National Technological University which started broadcasting in 1983, has taken some two and a half years to develop and is one of the first major achievements of the European Economic Community's COMETT programme, designed to promote collaboration between industry and universities in new technology.

The initiative for the project was that of Hewlett Packard, the US instrument and computer manufacturer, which has experience of business television in the United States. (The company uses satellite broadcasts for training its own staff, and held its fourth annual teleconference on medical ultrasonics, spanning the United States and Europe, only last Saturday.)

Four other European sponsors (British Telecom, IBM Europe, Philips and Thomson) helped to provide start-up capital for the scheme, while COMETT enabled universities to participate in its design. In the past two years, other sponsors have joined from France, Denmark, Spain, Portugal, the Netherlands, Italy and Scandinavia but there is none, as yet, from West Germany.

Technically, the project relies on the European regional communications satellite called Eutelsat (ECS), launched in 1985 and owned by a consortium of telecommunications authorities. The management of EuroPACE broadcasting and networking rests with France Telecom International, which owns the French satelite Telecom 1 (also launched in 1985, but not used for EuroPACE).

The materials on offer are in the fields of artificial intelligence and expert systems, telecommunications, program engineering, microelectronics, technology management and advanced industrial engineering. The courses are prepared and presented by international panels from industry and higher education. They are available to companies paying a 'sponsorship fee' of 25,000 ECU $(\$ 28,000)$, but at half that price to small businesses and universities. Users otherwise need only a parabolic receiving dish and an electronic mail account to use the facilities on offer, and to take advantage of the willingness of instructors to answer

\section{questions.}

Because the broadcasts are not encrypted, anybody with suitable equipment could receive the courses without having to pay a fee. But Hubert Curien, minister of research in the French government, says that for the sake of reaching as many people as possible for the smallest cost, the project will rely on the honesty of its audience for the time being.

Meanwhile, it seems to have been accepted that all broadcasts will be in English for the foreseeable future, which has implications for the face of technological Europe after the intended single common market comes into force in 1992. But whereas most science and technology students in Europe are used to reading English journals and textbooks, it is by no means certain that they will be equally skilled at following courses or formulating electronic mail questions in English.

The language problem is most acute in France, traditionally resentful of the increasing use of English neologisms as well as of 'linguistic imperialism' in science generally. Although EuroPACE may show that the position is softening, Curien says that it will be "absolutely essential" to encourage language learning. As multilingual broadcasting in Europe is still technically a long way off, EuroPACE may find that English courses are as germane to European competitiveness as its planned curriculum of high technology.

Peter Coles

\section{Investigation into Tajikistan earthquake}

\section{London}

Planners responsible for the building of an irrigation canal near Shashora village in Tajikistan, the Tajik capital, could face criminal charges, a TASS report from Dushanbe suggests. The special commission now investigating the cause of last month's earthquake and landslip in the Gissar valley are investigating whether seepage from the canal led to a dangerous build-up of groundwaters, and are seeking to establish why the village, built in such a vulnerable area, was not provided with mud-traps. The commission, said TASS, "may view the construction of the canal as critical". Mud-flows are a major hazard in the mountainous regions of Soviet Central Asia and the Caucausus. In 1973, such a flow almost overwhelmed AlmaAta, the capital of Kazakhstan, and in March 1987 Tajikistan suffered a major flood when a dam became clogged by mud and burst.

\section{Further fears of HIV in India}

\section{New Delhi}

FEARS of human immunodeficiency virus (HIV) contamination in the Indian blood pool have been heightened with the chance discovery of HIV antibodies in a widely used product derived from donors' blood. The government last week ordered a Bombay-based company, manufacturer of a wide range of blood products, to stop production and marketing of its products and has launched an investigation.

The government was alerted after the detection of HIV antibodies in samples of anti-rhesus (Rh) immunoglobulin, a vaccine routinely given to $\mathrm{Rh}$-negative mothers delivering $\mathrm{Rh}$-positive babies. The contaminated batch of vaccines has been on the market since August 1988, but officials said they did not know how many ampoules had actually been sold. The entire stock of the vaccines has been withdrawn from the manufacturer's retail outlets throughout India.

The contamination would have gone unnoticed had it not been that one purchaser of the vaccine was a physician at the All-India Institute of Medical Sciences (AIIMS) who casually asked a colleague to test it before injecting into his wife. Examination of more samples showed they were all positive for HIV.

Coming so soon after the discovery of HIV infection in eight out of 94 haemophiliacs screened last month at the AIIMS, the incident has scared the medical community as well as the lay public. But the AIIMS authorities say that women who might have received the contaminated vaccine are unlikely to develop AIDS because the vaccine has only antibodies to HIV, not the antigen itself. The Indian Health Organisation, a voluntary group in Bombay, has challenged this view and has threatened to sue the Bombay manufacturer and the government for having exposed the public to the risk of AIDS.

Under a statutory requirement, both imported and indigenous blood products must be certified free from HIV. But the health ministry admits that it has so far applied this rule only to imported products because it lacks the machinery and the resources to inspect and certify local products. There is no law at present to compel the screening of blood donors.

In the aftermath of the latest incident, the health ministry has decided to step up its surveillance of blood products. It has also directed the Indian Council of Medical Research to investigate whether the procedures and technology used by the Indian manufacturers are adequate to ensure the safety of their products. 